\title{
The Meaning of Rajah and Its Impact: A Study of Indonesian Madurese Tribes' Belief in Kepping Classic Holy Book Based on Genetic Structuralism Lucius Goldmann
}

\author{
Abdul Basid \\ Anilla Febriaty Hermanda \\ UIN Maulana Malik Ibrahim Malang \\ E-mail: abdulbasid@bsa.uin-malang.ac.id/ \\ anilla.hermanda@gmail.com
}

\begin{abstract}
Rajah' is one of the ancestor's legacy which use by Madura's people, expecially who in Islamic boarding school of holy book until nowdays. 'Rajah' is still believed as one of amulet to keep a traditional holy book's from termite, one species of the insect. This study wants to know and to investigate the opinion of Madura's people about 'rajah' to their credibility to keep the traditional holy book's based on genetic structuralism's perspective. The results of this study are: a) the facts of humanity expresses when people put rajah in their holy books, their holy books will not be eaten by termite; b) collective subject represents teacher's order to write rajah; c) worldview elaborates the function of rajah will work if the user believe in it; d) the structure of literary reflects one's believe in the truth happening after they use rajah; and e) the dialectical method of understanding explanations refers to all available concepts. Thus, we can understand from facts of humanity, worldview, and structure of literary.
\end{abstract}

Keywords: The Impact of Rajah, Madurese Tribe, Believe System, Genetic structuralism 


\section{INTRODUCTION}

Rajah or azimuth is hijaiyah letters or numbers arranged in such way which then is belief to eliminate danger or other belief. The arrangement of this letters is not at random, because in each letter, there is a value to determine the precise of azimuth preparation (Labib: 150).

The term rajah is an article or code which usually be used as azimuth to protect something. One of the purposes of rajah is as prayer and has magical and mystical arrangement (Gacek, 1986: 49). Rajah can be in a form of sign, certain script placed in an area to avoid themselves or the thing to unwanted things. Rajah can be in a form of a certain sentences which is read out in a glass or water or something else.

The script of rajah is not only in one form, yet the script can be formed suitable with the need and purpose that written by rajah. As we want to elimnate worrry or when we want to take a ablution, azimuth is written in a form of big and small circle side by side which then surrounds with hijaiyah letters that being decapitated (Ahmad, 622: 244).

In the era of growing technology, the used of rajah around people especially Madura's people is still very condensed. Considering all the activity which already switch to modern things, Madura people still very care and protect the tradition ans custom which had already used for a long time.

The majority user or rajah is santri salaf which still study to use yellow holy book or classic book. From there, teacher usually delivers orally about how to protect those holly book. Moreover, teachers in pondok salaf (term for Islamic students stay) generally their sanad study is clear and coherent, so what they receive will deliver clearly to the santri.

Meanwhile, the term Madura in essence appears because educated people of brahma come to a beautiful island. Therefore, it is become one of the reasons of the word Madura, form Sanskrit language. From that, Madura Island as though not become part of Java Island due to that name (Rifai, 2017:31)

Madura's people, especially who originally know the culture and the details of the realm, they seem familiar. From that reason, there is a dependency to the nature and environment which then born an animism belief (Rifai, 2007: 31). 
Due to their strong belief toward the nature and the environment, Madura's people believe that there is a strong correlation between who die and who alive. Therefore, as in Javanese people generally, the belief toward spirits is often called as kejawen. By the same token, in Madura Island, it is also believe to the spirits in the nature. Yet, their belief gradually decrease and replaced with the religion concept which is more structured (Rifai, 2007: 32). Various beliefs enter from foreign trader, because indeed soil structure of Madura which is less fertile compare to Java Island. From that belief, some myths which frequently consider as supernatural power is always happen due to their belief of Madura culture. One of the myths that still used until now is rajah behavior. Rajah has meaning to protect things in a form of classic book. Based on some literature, there is an interesting statement that rajah come from Persian Language which consists of various concept. The meaning from that word is the king of all insects. Not surprisingly, those word uses to protect their holy books (Sya'ban, 2011).

Based on previous study which was conducted on 18 March 2017 in Pademawu, Pamekasan Madura, the majority of Madura's people especially santri in pondok salaf believed in the existence of rajah and still believe of the truth particularly rajah placed inside the classic book. They believe that rajah which written with arrangement of the word like this "بكيكج" could avoid termite from the books. As it is known that books, papers, let alone classic book potentially become termite food, so after years that could not be read again.

Looking from the history, there is a letter which stated that rajah come from the Suryani language which sounds like "كيكج". It is originally from a tree name in which the tree is a tree which insects are afraid of. In brief, it is become one of the reasons why it is believed to drive out insect ( $\mathrm{Al} \mathrm{Jamal,2007:15).}$

Rajah especially which arrange from Arabic letter not instantly could be created as we want. This set has its arrangement that could be used as a pattern and it trusted the truth. Interestingly to be noticed is the hidden meaning behind the arrangement of the words, so it is became the belief of Madura's people in protecting the classic of holly books.

The phenomenon of rajah in Madura's people to protect the yellow holy book is appropriate and interesting if we see it in the point of view of Goldmann Genetic Structuralism theory. Rajah and 
social facts in Madura's people is always related. Hence, it is impossible to somebody to investigate about those alphabetic order and structure if there is no social fact. The world's viewpoint, which always becomes attention for santri salaf, is no different. A collective subject is needed to understand and explain rajah because an individual subject is not enough.

Goldmann argues that the knowledge about humanity facts will still be abstract if it is not concretized and integrated into the whole structure. In this genetic structuralism, there is dialectic theory which has two concepts. One of them is understanding and explanation. Both are being learned to know and comprehend the identity and significance of part by placing it into whole. Beside dialectic understanding and explanation, there are concepts of creation structure, world's viewpoint, and collective subject. They all are related to each other even though they have their own structures (Faruk, 2013: 77-79).

As a theory, genetic structuralism is seen as a true statement about reality. However, this statement can be true if it contains the illustration of systematic and integrated life, about the truth of (ontology) and idea in understanding the statement above (epistemology) (Faruk, 2015: 56).

Although this genetic structuralism theory is based on the Marxism theory, both are still two different theories. Marxism theory rejects the structure of positivistic. It also refuses to use it. Nevertheless, the structuralism still maintains the structure of dialectic method and uses it. Therefore, the structuralism is called para-Marxism and neo-Hegelian because renewing the dialectic of Hegel (Ratna, 2007:122).

Based on the explanations above, this study will be investigated the mean of rajah in genetic structuralism theory which Madura's people still has believe in. The focus is taken from the elements in genetic structuralism namely humanity facts, collective subject, world's viewpoint, literature work structure, and dialectic of understanding-explanation about rajah on Madura's people believe in the protection of the classical book.

\section{METHOD}

This study used qualitative approach with phenomenology study because the researchers focused on the rajah phenomenon experienced and believed by Madura's people, especially santri Salaf 
Islamic high school (Putra, 2013: 37-38). The researchers chose rajah in Madura because Madura people still holds on to their belief about the use of rajah which can protect classical holly books from termite.

In this research, the data sources are primary data and secondary data. The primary data source is the opinions from the users of rajah in keeping holly books. The secondary data source are documents, article and holly books about rajah.

To get valid and credible data, the researchers conduct credibility test (internal validity) on the collected data. This credibility test has three steps. They are improving perseverance by repeating and comprehending the collected data, triangular: source, technique, and time (Sugiyono, 2015: 270-274), and discussion with experts or friends (Moleong, 2012: 331).

The data collection techniques used in this study are observation (Moleong,200: 126 \& Rustanto, 2015: 61) and interview with the users of rajah (Setiyadi, 2006: 243 \& Rustanto, 2015: 58). After collecting data, the researcherss analyze the data. The researcherss start from reducing the data to choose the right primary and secondary data. After that, the data are presented and the researcherss make conclusion (Miles \& Huberman, 1994: 30).

\section{RESULT AND DISCUSSION}

\section{The Humanity Facts}

Based on the theory explained previously, humanity fact is a fact such as nature activity, politic or cultural creation. Goldmann states that the humanity fact has to consider its structure because it is bound with one purpose which becomes its meaning. It is done to reach balance with the surrounding (Faruk, 2016: 57-58).

According to Piaget (Goldmann, 1981: 61, cited in Faruk, 2016: 58 ), human and their surrounding are in the reciprocal structuring process that is contrast but filling each other. Hence, literature work based on the structuralism in the humanity fact's viewpoint is the part of assimilation process and accommodation (adjusting to reality) that reaching the balance continuously.

Based on the interview result, the researchers found that there were some opinions from some interviewees that belongs to humanity facts. "Kaula nules 'bikaikaji' ghaneka e ketab, biasana etoles e de'ade'na. Hasella, saampona abit tak epareksa, ghun sabegian se tak 
ekakan raprap, sakadhang e kolek luarrah ekakan ni' sakoni'." (Ri 29 April 2017)

After several years, the holy books with rajah written or not opened were deposited and saved. As a result, the fact, those holy books were properly not eaten by termites. According to him, there were some pages that were rajah written still legible and intact. Meanwhile, the rajah unwritten was still eaten by termites.

Furthermore, there was a phenomenon about rajah. If a holy book which has several rajahs written and the other was rajah unwritten, accordingly, the pages with rajah written would be intact and the other with rajah unwritten would be still eaten by termites.

There were many other phenomena occur due to rajah written in a holy book. A holy book could be completely intact with only one rajah written and in the front or at the end of the holy book. In addition, there was also a holy book that must be covered by rajah written in every page or fully covered in one page. As stated by him in the interview,

“Ketab ghaneka kaula saba' e dalem kardus pas epamasok ka lomare. Nalekana kaula pareksa saampona sanapa taon, bada sabagian ketab se bada tolesan 'bikaikaji'-na tak ekakan raprap. Ghi ghun ghaneka, se laen pagghun ekakan. Misallah salembar bada tolesan 'bikaikaji', ghaneka se tak ekakan. Ghir-pegghirra se tadak tolesanna pagghun ekakan." (R1 29 April 2017).

Various kinds of phenomena that occur showed that there were many kinds of rajah and they have various kinds of result. However, those various results did not dampen the rajah users to stop using it but based on the interviewees' activity, the fact stated that Rajah was still used by them who graduated from Islamic boarding house. It was because according to them, teacher's statement is a knowledge which has to be followed.

\section{Collective subject}

After the researchers explained about the humanity facts, the researchers would be discussing the collective subject in the next discussion. In the humanity facts, it was stated that fact didn't come out anywhere, but it was the result of human activities. They could be the result of collective or trans-individual work (Faruk, 2016: 6264). Social class did not come from an association of individual, but it was a community which has similarity in the idea, though and 
aspiration, so it can be distinguished from other social groups (Wiyatmi, 2013: 136).

Based on the interview between the researchers and the interviewee, actually, the collective subject was not described significantly as explained in the previous theory about the upper group and lower group. However, in the interview process, the researchers found an indication about that collective subject. It was about the rajah users who did not believe in the meaning of the writing and the users who believe in the meaning of rajah writing. In the fact, there was no class classification, but it could be clearly seen if a student who got knowledge from the teacher, or when the teacher asked the students to place rajah with "bikaikaji" writing in a holy book with the purpose was to keep it from termites, the students would follow the teacher and wrote it based on the teacher's instruction.

Despite belief or not with the truth revealed by the teacher, the students keep writing it. The trust will be change if the students found the evidence that really happened and in accordance with what the teacher said. As stated by one of the interviewees that:

"Kaula nules 'bikaikaji' polana nuro'e dari bangatua se sabellumma, dari ghuru kaula, ghun nuro' bunte'. Tak oneng kadhiponapa panjhabharanna. Anapa kaula sareng panjhennengan pagghun ngangghuy ghaneka, ghi polana nuro'e se dari attassa tor kabiasaan se elakoni bangatowa se ampon kaaa'. Kaula ghun oneng dari bangatowa, daddhi ghun nuro' nules. Manabi kaparcajaan ghi bhunten tak parcaja, ghun nules se ampon etoles."

Kaula tak oneng panjhabharanna kadhiponapa bhander napa bhunten, namung kanyataanna ghi kadhi ka'dissa" (R1 29 April 2017) Based on the interview result, the researchers found that there were some opinions from some interviewees that belongs to humanity facts. "Kaula nules 'bikaikaji' ghaneka e ketab, biasana etoles e de'ade'na. Hasella, saampona abit tak epareksa, ghun sabegian se tak ekakan raprap, sakadhang e kolek luarrah ekakan ni' sakoni'.". (R1 29 April 2017)

As a student, must do according what the teacher mentions, because teacher is everything and to get a blessed. In this rajah activity, belief in a teacher outweighs the belief in rajah what they wrote in their books. So the existence of a belief as an indication of the collective subject is not so problematic in this case. 
Worldviews

In this section, after discussing about collective subject and the humanity facts, the researcherss will discuss the world view that occurred on the use of rajah. The world view itself is an abstract notion of a class about human life and lifestyle that can unite intermembers with one another in the same class, and distinguish between members in different classes. So, the worldview is not necessarily present, but it requires a very long process, slowly creating a new mentality of the transformation of the old mentality (Faruk, 2016: 65-66).

In the concept of this worldview, Goldmann sees that between the literary structure and the social structure there are homology. It is related to the activity of literary structure with the community is a same. That is, literary is not a reflection about the content of society, but the literary has the same homology relationship in its structure, not in its substance (Ratna, 2007: 123).

Goldmann sees that the worldview is a holistic view, a coherent and integrated perspective of humanity, and the relationship between humans and the universe as a whole.

In a field study that researcherss have done, researcherss found that the user's worldview of rajah is exactly the same as the user's view of medicine for pain. When the user believes in the medicine he is going to heal, then he will recover, so also with this bikaikaji, if someone believes that rajah can avoid the book from termites, it will happen.

But that belief not only believes blindly, users trust rajah, because it is what keeps the book to remain intact is God. As in the explanation:

"Kaula oneng dari oreng laen manabi nules 'bikaikaji' maka tak ekakan raprap, daddhi ghi kaula nules jhugha. Biasana ghaneka ghabai pagobhathan, otaba anolak tong-settong. Manabi kaparcajaan, se mabaras ghun Allah. Lebat du'a."

"ghaneka ghun dari oreng, manabi panjhabharan e ketab ghita' epangghi. Ghitk paste ekakan raprap. Ghi manabi Allah mabarassa pagghun baras. Bikaikaji ghun parantara. Jimat bada se makafer polana parcaja da'jimatta banni ka Allah. "(R2 April 29, 2017)

Some users also say that when they write bikaikaji, they also must keep the book in such a way, not only placed in any place, because in possibility that the book will also be the consumption of termites. As in his explanation: "Kaula tak pacaja ka rajhaan 
ghaneka, ghun nyoba' saos, ban bada se ahasel, bada jhugha se tadak hasella. Tor se nantoaghi kabbhi ghi Allah. Se tak ahasel berarti nyaba'na se tak bhander. " ( $\mathrm{R}_{3}$ March 18,2017$)$

What the reason for something done, or how effective to heal something else, if not belief in the results, will not have any impact. Like the user of rajah, someone who uses rajah has a much belief that if using this rajah will be spared from termites. But if the trust has been scratched even a little, and he does not fully believe, anything that feared in his heart will actually happen. Because all of something will be in accordance with what is believed and thought. Good thoughts will get good results and bad thoughts will get bad results. Rajah is also included in that category.

\section{Structure of Literary}

In the next section, researcherss will discuss the structure of literary. The structure of the literary is the relationship between the one character with the other character, or relationship between the figure with the object. But, the structure of Goldmann's literary is thematic that focuses on the relation between figures and the surrounding objects. Therefore, the understanding of the origin of the structure of literary can't be separated from the author and his social group, the worldview of the author's social group, and the structure of society (Wiyatmi, 2013: 130).

The structure of literary that became the study in this research is relationship between the figure with the object studies. To explain how the structure of literary in this research is relation between character with yhe object.

The explicit relation is when the users of rajah used rajah, they will belief first of all to their teacher who give them advice to use rajah. Because a student must also belief to their teacher thoroughly. That's all seem in informan's information about sructure of literary that one of structure of other literary.

"Manabi kaula nules, kaula yakin. Tor hasellah bhander maka seekalako bhander."

"kaparcajaan, ghan ka'dimma kaparcajaan ban paghabdhian kaula sareng panjhennengan ka Allah."

"Biasana e bulan safar e rabu dibudi eparenta kaangghy nules aeng rajhaan." (R4 29 April 2017)

Besides people's belief on teacher, the other belief is to the rajah itself. It depends on how big the spiritual level of the rajah 
user. For some people who know for the very first time, belief on the things that his teacher actually does is necessary to do. Moreover, for the non-layman, it is divided into two parts, one of them is for people with low spirituality, they will do with no much pressure especially with what they should believe and do. It can also have an impact on increasing the user's spirituality or even degrading the spirituality itself by believing in it without further study. In addition, for users who have a high level of spirituality, rajah is just as a tool to bring us closer to the Almighty

"Manabi parcaja da' rajhaan ghaneka paste bada pangarona da' dharajhat kaimaman oreng se ngangghuy rajhaan, sakabbhina ka'dissa taghantong da' rajhaaan kaangghuy kabhaghysan. Artena se kodhu etamen e dalem ate engghi ka'dinto yakin. Manabi sera se lebbi kada' abharri' pangaro taghantong orengga, ghan ka'dimma tegghina dharajhatta oreng se ngangghuy rajhaan."( $R_{3}$ March 18 , 2017).

So the main frame in this research is a trust formed based on how big the spiritual level of the rajah user itself. These levels can be classified as teacher beliefs and then move on to the belief that rajah trust and its spirituality have a very close relationship so that the impact will also be seen from objects or written books.

\section{Dialectics: Understanding}

After discussing the main frame of literary works, the next discussion is the dealiectics of the explanations and the whole-part. Dialectics is a method that not only focuses on the text of literary works, but also relates to the coherence of existing structures.

The basic principle of this dialectical method, Goldmann argues that knowledge of the facts of humanity will remain abstract if not cleared and upgraded into the overall structure. In this dialectic theory there are also two concepts which one of them is understanding and explanation. Both of these are learned to know and understand the identity of the part and the meaning of the passage by placing it in whole parts (Faruk, 2016: 77-79).

Goldman, 1970 (in Faruk, 2016) asserted that understanding is a tight structure of descripstion from object that have been studied, while explanation is an attempt to blending some definitions into some stutructures bigger. It means placing a part into a larger section to know and understand the identity of the part itself. 
In this case researcherss need an understanding of the facts of humanity that already exist and has been written in the discussion of facts of humanity, in which facts of this humanity also needed an understanding of the structure of literary works that will give birth to the understanding of the whole-part.

Then, after understanding of the whole passage, it is necessary to integrate the understanding by uniting and analyzing the world view of the society against the tusk from the collective subject that has been described, thus giving birth to an understanding of deeper explanations. This explains that the worldview of society has the same expression of a belief that exists in it, so it is with that belief that will take it out of the context of the tattoo itself, which is connected with belief in God.

\section{CONCLUSION}

Based on the discussion above, the conclusions found in this study are as follows: a) the fact of humanity in the use of rajah in the classic book is a fact that occurs when someone put rajah in his book, the book will be protected from termites; b) the collective subject present in the usage of the rajah revolves around the rajah user's belief in the facts that have occurred and the belief is usually obtained by the instruction of the teacher to write the rajah; c) the worldview explains that rajah will be possible if the rajah user trusts the rajah, so the world perceives rajah as sickly to the medicine; d) the structure of literary works in the use of rajah is one's belief in the truth that occurs after the use of rajah itself; and e) the dialectic of understanding and explanation refers to all the concepts that have been presented, so that it can take the understanding of the facts of humanity and worldview which are then described based on the existing work structure.

The cultural and linguistic reviewers are needed to give more attention to the development of scholarship. Since in cultural studies in particular, many cultures still have not been raised to the surface and are in desperate need of scientific analysis, because in in this research, the culture that researcherss adopt is still limited to the hereditary cultures that down to earth know the ins and outs of that culture. Therefore, the researcherss put forward some suggestions or recommendations to cultural activists and further researcherss, even to the readers. 
Overall, this research is still far from perfect, however, the researcherss strive to explain how the views of society about tattoos that have been used for generations. I hope that this research can provide an increasingly clear understanding of a culture that exists in classical society.

\section{REFERENCES}

Ahmad, Imam. (622 H). Syamsul Maarif Wa Li Thoifi Al Awarif. Surabaya: Al Hidayah.

Al Jamal, Syekh Ahmad Muhammad Ali. (2007). Alquran Wa Lughat Al-Suraniyah. Majalah. Mesir: Universitas Al-Azhar.

Faruk. (2016). Pengantar Sosiologi Sastra: dari Strukturalisme Genetik sampai Post-Modernisme. Yogyakarta: Pustaka Pelajar.

Gacek, Adam. (1986). The Use of 'Kabikaj' in Arabic Manuskripts. Netherland: Ter Lugt Press.

Labib. Primbon Mujarobat kubro: Warisan Leluhur. Surabaya: Gali Ilmu.

Miles, Matthew B \& A Michael Hubermann. (1994). Qualitative Data Analysis (Second Edition). London: Sage Publication.

Moleong, Lexy. J. (2005). Metodologi Penelitian Kualitatif. Bandung: Remaja Rosdakarya

Moleong, Lexy. J. (2012). Metodologi Penelitian Kualitatif. Bandung: PT. Remaja Rosdakarya.

Putra, Nusa. (2013). Penelitian Kualitatif IPS. Bandung: PT Remaja Rosdakarya.

Ratna, Nyoman Kutha. (2007). Teori, Metode, dan Teknik Penelitian Sastra: Dari Strukturalisme hingga Postruktukturalisme Perspektif Wacana Naratif. Yogyakarta: Pustaka Pelajar.

Rifai, Mien Ahmad. (2007). Manusia Madura.Yogyakarta: Pilar Media (Anggota IKAPI).

Rustanto, Bambang. (2015). Penelitian Kualitatif Pekerjaan Sosial. Bandung: PT Remaja Rosdakarya.

Setiyadi, Ag. Bambang. (2006). Metode Penelitian Untuk Pengajaran Bahasa Asing; Pendekatan Kuantitatif dan Kualitatif. Yogyakarta:Penerbit Graha Ilmu

Sugiyono. (2015). Metode Penelitian Kuantitatif, Kualitatif dan $R \mathcal{E} D$. Bandung: Alfabeta. 
Abdul Basid

Sya'ban, A. Ginandjar. (2011). Kabikaj, Lafadz Jimat di Muka Kitab. Diakses di http://pesantrenkuuu.blogspot.com/2011/o4/ pada tanggal 25 Maret 2017

Wiyatmi. (2013). Sosiologi Sastra: Teori dan Kajian terhadap Sastra Indonesia. Yogyakarta: Kanwa Publisher. 